\title{
Effect of socio-economic determinants on gross income of dryland farm in Nanded district of Maharashtra
}

\section{B.R. PAWAR, P. U. KAUTHEKAR AND R. A. KOLAMBKAR}

Received : 30.05.2015; Revised : 04.08.2015; Accepted : 05.09.2015

\begin{abstract}
Investigation was carried out during the year 2013-14. In all 48 dryland farms were randomly selected from sixteen villages of two tehsils in Nanded district of Maharashtra. Data were related to cropping pattern and livestock pattern as well as socioeconomic determinants. The results revealed that livestock showed highly significant on dryland farm with regression coefficient of 10153.10. It means that addition of one livestock could cause to increase Rs. 10153.10 of gross income on dryland farm. In next order, regression co-efficient of educational level was 8443.59. It means that addition of one score of educational level, it would lead to increase Rs. 8443.59 on dryland farm. On the contrary, distance of farm from village showed regression co-efficient of -3260 which was negatively significant. If addition of one kilometer distance to existence distance, it could adversely affect gross income of Rs. 3260.42 on dryland farm. Thus, dryland farmer has to give more importance to livestocks, educational level and distance of farm from village in order to increase in gross income on dryland farm.
\end{abstract}

KEY WORDS : Dryland farm, Regression co-efficient, Gross income, Linear function

How to cite this paper : Pawar, B.R., Kauthekar, P.U. and Kolambkar, R.A. (2015). Effect of socio-economic determinants on gross income of dryland farm in Nanded district of Maharashtra. Internat. J. Com. \& Bus. Manage, 8(2) : 167-170.

\section{MEMBERS OF THE RESEARCH FORUM}

Correspondence to:

P.U. KAUTHEKAR, Department of Agricultural Economics, College of Agriculture, Vasantrao Naik Marathwada Krishi Vidyapeeth, PARBHANI (M.S.) INDIA

Email: pandurangk15@gmail.com

Authors' affiliations:

B.R. PAWAR AND R.A. KOLAMBKAR, Department of Agricultural Economics, College of Agriculture, Vasantrao Naik Marathwada Krishi Vidyapeeth, PARBHANI (M.S.) INDIA

Email: kolambkar.rachana14@gmail.com 